\title{
Physics education research as a guide for improving the teaching and learning of physics: an example from optics
}

Karen Wosilait

Karen Wosilait, "Physics education research as a guide for improving the teaching and learning of physics: an example from optics," Proc. SPIE 9663, Eighth International Topical Meeting on Education and Training in Optics and Photonics, 966310 (6 October 2003); doi: 10.1117/12.2208472

SPIE Event: Eighth International Topical Meeting on Education and Training in Optics and Photonics, 2003, Tucson, Arizona, United States 


\title{
Physics education research as a guide for improving the teaching and learning of physics: an example from optics
}

\author{
Karen Wosilait \\ University Preparatory Academy, Seattle, Washington and the University of Washington, $800025^{\text {th }}$ Avenue NE, Seattle, Washington 98115 \\ telephone: (206) 525-2714, extension 177; fax: (206) 525-9659; e-mail: kwosilait@universityprep.org
}

\begin{abstract}
The Physics Education Group at the University of Washington has been investigating student understanding of geometrical and physical optics. The results of this research have guided the design of two curricula. Examples will be given of serious student difficulties and how they are addressed through these research-based curricula.

(C)2003 Optical Society of America
\end{abstract}

OCIS codes: (000.2060) Education; (000.2170) Equipment and techniques

The Physics Education Group at the University of Washington has been investigating student understanding of optics. Findings indicate that many students who have studied physics at the introductory level and beyond cannot apply basic principles from geometrical optics to account for the pattern produced when an aperture is placed between a light source and a screen. Identification and analysis of student difficulties have guided the design of two curricula: one to supplement instruction in lecture-based university courses (Tutorials in Introductory Physics) and one for the preparation of pre-college teachers (Physics by Inquiry). Ongoing assessment was an integral part of the curriculum development process. The instructional materials that evolved from this iterative cycle have proved to be effective with the target populations. In addition, with appropriate preparation, pre-college teachers can effectively adapt the materials for use in their own classrooms.

This work was supported, in part, by the National Science Foundation.

\section{References}

Tutorials in Introductory Physics, L.C. McDermott, P.S. Shaffer and the Physics Education Group at the University of Washington, Prentice Hall (2002).

Physics by Inquiry, L.C. McDermott and the Physics Education Group at the University of Washington, Wiley (1996).

Eighth International Topical Meeting on Education and Training in Optics and Photonics,

edited by Barry L. Shoop, Grover Swartzlander Jr., Proc. of SPIE Vol. 9663, 966310

(C) 2003 SPIE, OSA, ICO · doi: 10.1117/12.2208472 